\title{
The Metabolism of Aromatic Ring Fission Products by Bacillus stearothermophilus Strain IC3
}

\author{
By DAVID ADAMS $\uparrow$ AND DOUGLAS W. RIBBONS* \\ Centre for Biotechnology, Imperial College of Science and Technology, London SW7 2AZ, UK
}

(Received 18 March 1988; revised 1 August 1988)

Bacillus stearothermophilus IC3 degraded the meta cleavage product of catechol, 2hydroxymuconic semialdehyde, to pyruvate and acetaldehyde via the 4-oxalocrotonate pathway. The pathway was identical to those previously delineated in several mesophilic organisms. However, all the enzymes showed activity at $55^{\circ} \mathrm{C}$ and other properties (substrate specificities and effects of metal ions) also differed from those displayed by the mesophilic enzymes. All enzymes of this meta cleavage pathway, except the 2-hydroxy-6-oxohepta-2,4dienoate hydrolase and 4-hydroxy-2-oxovalerate aldolase activities, were induced by growth on phenol.

\section{INTRODUCTION}

A number of thermophilic bacteria are able to utilize aromatic compounds as carbon and energy sources. A thermophilic Bacillus was able to metabolize benzoate and p-hydroxybenzoate, via gentisate, to pyruvate and fumarate (Buswell \& Twomey, 1974; Buswell \& Clark, 1976). Thermus strains utilizing phenylacetate as a carbon source have also been observed (Degryse et al., 1978). The metabolism of phenol by unidentified thermophiles (Egorova, 1942, 1946) and Bacillus stearothermophilus strains (Buswell, 1974, 1975; Buswell \& Twomey, 1975; Golovacheva \& Oreshkin, 1975) has also been widely described.

An earlier report (Adams \& Ribbons, 1988) established that a number of thermophilic bacilli were able to grow on aromatic compounds, including benzoate, $p$-hydroxybenzoate, phenylacetate, $p$-hydroxyphenylacetate, L-phenylalanine and phenol. One of these organisms, Bacillus stearothermophilus IC3, metabolized phenol to 2-hydroxymuconic semialdehyde via catechol. In this paper we describe the further metabolism of 2-hydroxymuconic semialdehyde to pyruvate and acetaldehyde.

\section{METHODS}

Isolation, growth media and growth conditions of Bacillus stearothermophilus IC3. These were as described by Adams \& Ribbons (1988).

Chemicals. Most chemicals were obtained from major manufacturers (Aldrich, Lancaster Synthesis, Sigma). Authentic 4-oxalocrotonate and 4-methyl-2-oxobutyrolactone were synthesized according to the methods of Lapworth (1901), and Rossi \& Schinz (1948), respectively, by Dr John Roesiter of this department. 2Hydroxymuconic semialdehyde and its methyl substituted analogues were generated in situ by the action of a catechol 2,3-dioxygenase present in strain IC3 (Adams \& Ribbons, 1988) upon catechol and methyl catechols. 4 Hydroxy-2-oxovalerate was prepared by mild alkaline hydrolysis of 4-methyl-2-oxobutyrolactone (Dagley \& Gibson, 1965).

† Present address: Biological Laboratory, University of Kent at Canterbury, Canterbury, Kent CT2 7NJ, UK.

Abbreviations: HOD, 2-hydroxy-6-oxohepta-2,4-dienoate; HODH, 2-hydroxy-6-oxohepta-2,4-dienoate hydrolase; HMS, 2-hydroxymuconic semialdehyde; HMSD, 2-hydroxymuconic semialdehyde dehydrogenase; HMMS, 2-hydroxy-5-methylmuconic semialdehyde; OC, 4-oxalocrotonate. 
The preparation of 2-oxopent-4-enoate was based upon the methods of Collinsworth et al. (1973). A $10 \mathrm{ml}$ solution containing $250 \mu \mathrm{mol}$ Tris buffer (pH 8.2), $0.5 \mathrm{mmol} \mathrm{DL}$-allylglycine, 25 units D-amino acid oxidase and 1250 units catalase, was incubated at $25^{\circ} \mathrm{C}$ for $30 \mathrm{~min}$. The solution was then acidified to $\mathrm{pH} 1.5$ with $\mathrm{HCl}$, and the product extracted twice with $25 \mathrm{ml}$ diethyl ether. The ether was removed and the precipitate resuspended in $5 \mathrm{ml}$ dilute $\mathrm{HCl}(\mathrm{pH} 1.5)$. The solutions were stored at $-20^{\circ} \mathrm{C}$ and used within 1 week.

The following enzymes were obtained from Sigma : aldehyde dehydrogenase (EC 1.2.1.5) from bakers' yeast; D-amino acid oxidase (EC 1.4.3.3) from porcine kidney; catalase (EC 1.11.1.6) from bovine liver; formate dehydrogenase (EC 1.2.1.2) from Pseudomonas oxalaticus; NADase (EC 3.2.2.5) from Neurospora crassa; and pyruvate dehydrogenase from bovine heart.

Cell-free extracts. These were prepared from 1 litre cultures that had been harvested in the mid-exponential growth phase. The cells were washed twice in 50 mM-potassium phosphate buffer $(\mathrm{pH} 7.0)$ at room temperature, and then resuspended in $5 \mathrm{ml}$ fresh buffer containing $10 \%(\mathrm{v} / \mathrm{v})$ acetone and $0.5 \mu \mathrm{mol}$ phenylmethylsulphonyl fluoride. The resuspended cells were then sonicated for $15 \mathrm{~s}$, at an amplitude of $16 \mu \mathrm{m}$, with intermittent cooling to $4^{\circ} \mathrm{C}$, for a total of $3 \mathrm{~min}$. The extracts were subsequently clarified by centrifugation at $35000 \mathrm{~g}$ for $40 \mathrm{~min}$ at $4^{\circ} \mathrm{C}$. The cleared extracts were stored at $4^{\circ} \mathrm{C}$ until used. For all assay procedures the extracts were diluted in $50 \mathrm{~mm}$ potassium phosphate buffer (pH 7.0). Protein concentrations were measured by the method of Bradford (1976), using Bio-Rad Protein Assay Reagent. Bovine serum albumin was used as a standard.

Determination of enzyme activities. All enzyme rates shown are the mean of at least two results. All assays were done with cell-free extracts, at protein concentrations of $0.3-0.5 \mathrm{mg} \mathrm{ml}^{-1}$, diluted in $50 \mathrm{~mm}$-phosphate buffer (pH 7-0). 2-Hydroxy-6-oxohepta-2,4-dienoate hydrolase (HODH) was assayed by following the disappearance of 2-hydroxymuconic semialdehyde (HMS), 2-hydroxy-6-oxohepta-2,4-dienoate (HOD) or 2-hydroxy-5-methylmuconic semialdehyde (HMMS) at 375,388 and $382 \mathrm{~nm}$ respectively. The molar absorption coefficients $\left(1 \mathrm{~mol}^{-1} \mathrm{~cm}^{-1}\right.$ ) at $\mathrm{pH} 7.0$ were calculated as: HMS, 27900; HOD, 7600; HMMS, 20200 (Adams \& Ribbons, 1988). 2-Hydroxymuconic semialdehyde dehydrogenase (HMSD) was assayed in the same manner as HODH, except that NAD was added to a concentration of $1 \mathrm{~mm}$; the rate of degradation before the addition of NAD was subtracted from the value obtained.

4-Oxalocrotonate tautomerase was assayed by measuring the initial rate of decrease in absorbance at $292 \mathrm{~nm}$ on addition of 4-oxalocrotonate. Rates are expressed as the rate of decrease in absorbance at $292 \mathrm{~nm}(\mathrm{mg}$ protein $)^{-1} \mathrm{~min}^{-1}$, corrected for a spontaneous tautomerization of 3.3 absorbance units $\mathrm{min}^{-1}$.

4-Oxalocrotonate decarboxylase activity was assayed by following the disappearance of the substrate. The total 4-oxalocrotonate concentration was obtained by adding $100 \mu 10 \mathrm{M}-\mathrm{NaOH}$ to $1 \mathrm{ml}$ of the reaction mixture and reading the absorbance at $350 \mathrm{~nm}$. The molar absorption coefficient of authentic 4-oxalocrotonate was 20800 units $\mathrm{cm}^{-1}$ at this wavelength.

2-Oxopent-4-enoate hydratase activity was determined by following the disappearance of the substrate. The substrate concentration was determined by HPLC analysis after the addition of $20 \mu$ concentrated $\mathrm{HCl}$ to $100 \mu \mathrm{l}$ of sample. All rates were corrected for a spontaneous disappearance of 2-oxopent-4-enoate. Due to the instability of the substrate, previous workers have expressed the activity of this enzyme in units of absorbance at $265 \mathrm{~nm}$ (mg protein) ${ }^{-1} \min ^{-1}$. The hydratase activities have therefore been converted into the same units. 4-Hydroxy-2oxovalerate aldolase was assayed by converting the residual substrate to its lactone (Dagley \& Gibson, 1965) and measuring this by HPLC analysis. The HPLC analyses of 2-oxopent-4-enoate and 4-methyl-2-oxobutyrolactone were done using a mobile phase of $20 \%(\mathrm{v} / \mathrm{v})$ propan-2-ol and $8 \mathrm{~mm}$-orthophosphoric acid. A Spherisorb $10 \mathrm{Cl}$ reverse phase column was used. With a UV monitor operating at $270 \mathrm{~nm}$, and a mobile phase flow rate of

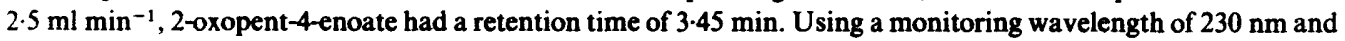
a flow rate of $1 \mathrm{ml} \mathrm{min}^{-1}$, the 4-methyl-2-oxobutyrolactone had a retention time of $4 \cdot 18 \mathrm{~min}$.

Identification of intermediates. 4-Oxalocrotonate $(\mathrm{OC})$ was isolated and identified as follows: a $50 \mathrm{ml}$ phosphate buffer (pH 7.0) solution containing $5 \mu \mathrm{mol}$ HMS, $10 \mathrm{mg}$ cell-free extract protein, $50 \mu \mathrm{mol}$ NAD and $250 \mu \mathrm{mol}$ EDTA was incubated at $55^{\circ} \mathrm{C}$ until the yellow colouration had disappeared. The solution was then acidified to pH 1.5 with concentrated $\mathrm{HCl}$ and the precipitate removed by centrifugation. The product was then extracted from the supernatant three times with $50 \mathrm{ml}$ ethyl acetate. After drying over anhydrous $\mathrm{MgSO}_{4}$ and removal of the ethyl acetate by rotary evaporation, the precipitate was dissolved in ethanol. Adding $50 \mu \mathrm{l}$ of this solution to $1 \mathrm{ml}$ phosphate buffer (pH 7.0) gave a spectrum with a peak at $292 \mathrm{~nm}$ that disappeared within 5 min, resulting in the production of a new peak within the $235-240 \mathrm{~nm}$ region. On addition of $100 \mu 110 \mathrm{M}-\mathrm{NaOH}$ a peak with a wavelength of $350 \mathrm{~nm}$ appeared. These spectral characteristics are consistent with those reported for 4oxalocrotonate (Sala-Trepat \& Evans, 1971 a).

2-Oxopent-4-enoate was analysed by HPLC analysis. A $10 \mathrm{ml}$ phosphate buffer solution containing $5 \mathrm{mg}$ cellfree extract was incubated at $55^{\circ} \mathrm{C}$. The transient appearance of an intermediate with the same retention time as authentic 2-oxopent-4-enoate $(3.45 \mathrm{~min})$ was observed. The intermediate, like the authentic compound, was also unstable in alkaline solution.

HPLC analysis was also used to monitor 4-hydroxy-2-oxovalerate. A phosphate buffer solution (1 ml) containing $0.5 \mathrm{mg}$ cell-free extract protein, $1 \mu \mathrm{mol} \mathrm{MgSO}_{4}$ and $100 \mu \mathrm{l}$ of the 2-oxopent-4-enoate preparation was 
incubated at $55^{\circ} \mathrm{C}$. After $1 \mathrm{~min}$ the product reached its maximum concentration ( $\left.22 \cdot 1 \mathrm{~mm}\right)$, and thereafter slowly disappeared.

Pyruvate was determined enzymically by a method based upon that of Brown \& Perham (1976). Cell-free extract solutions $(1 \mathrm{ml})$ were held at $100^{\circ} \mathrm{C}$ for $30 \mathrm{~min}$ to destroy any thermophilic NADH oxidase activity. The samples were clarified by centrifugation and $0.5 \mathrm{ml}$ was added to a cuvette. To the sample was added: NAD, $1 \mu \mathrm{mol}$; thiamin pyrophosphate, $0.2 \mu \mathrm{mol} ; \mathrm{MgSO}_{4}, 2.6 \mu \mathrm{mol}$; pyruvate dehydrogenase, 0.25 units. The samples were made up to $1 \mathrm{ml}$ with $50 \mathrm{~mm}$-phosphate buffer $\left(\mathrm{pH} \mathrm{7.0)}\right.$ and incubated at $30^{\circ} \mathrm{C}$. The pyruvate concentrations were determined by following the production of NADH as absorbance at $340 \mathrm{~nm}$.

Acetaldehyde was determined by the method of Lundquist (1958). The NADH oxidase activity was destroyed in the same manner as for pyruvate measurements. A $0.5 \mathrm{ml}$ sample was added to a cuvette together with: NAD, $1 \mu \mathrm{mol}$; L-cysteine, $1 \mu \mathrm{mol}$; aldehyde dehydrogenase, 0.25 units. The samples were made up to $1 \mathrm{ml}$ with 50 mMphosphate buffer (pH 7.0), and incubated at $25^{\circ} \mathrm{C}$. Acetaldehyde concentrations were also measured by following NADH production as absorbance at $340 \mathrm{~nm}$.

\section{RESULTS}

Table 1 shows the rates of disappearance of the ring fission products of catechol and the methylcatechols and the effects of NAD upon these rates. Chemical and enzymic analyses were consistent with formate being a product of HMS metabolism in the absence of NAD. A $4 \mathrm{ml}$ solution of $50 \mathrm{~mm}$-phosphate buffer containing $2 \mathrm{mg}$ cell-free extract protein was incubated with HMS for $1 \mathrm{~h}$ at $55^{\circ} \mathrm{C}$. During this time, $224 \mathrm{nmol} \mathrm{HMS}$ (calculated from the decrease in absorbance at $375 \mathrm{~nm}$ ) was metabolized. A total of $180 \mathrm{nmol}$ formate was produced when assayed by the method of Grant (1948), a yield of $80 \%$.

Formate was also detected enzymically using formate dehydrogenase. A $3 \mathrm{ml}$ sample containing $1.2 \mathrm{mg}$ cell-free extract protein in phosphate buffer metabolized $48 \mathrm{nmol} \mathrm{HMS}$ with the production of $42 \mathrm{nmol}$ formate, an $88 \%$ yield.

The product of HMS degradation in the presence of NAD was isolated and identified by its spectral characteristics as 4-oxalocrotonate. To establish the stoicheiometry of the reaction, cuvettes containing $50 \mathrm{nmol}$ HMS, $0.4 \mathrm{mg}$ cell-free extract, $1 \mu \mathrm{mol}$ NAD and $5 \mu \mathrm{mol}$ EDTA in $1 \mathrm{ml}$ phosphate buffer were incubated at $55^{\circ} \mathrm{C}$ until the semialdehyde had been completely metabolized. On completion of the reaction $100 \mu \mathrm{NaOH}(10 \mathrm{M})$ was added. A new peak at $350 \mathrm{~nm}$ was observed, corresponding to $52 \mathrm{nmol} 4$-oxalocrotonate, a yield of $104 \%$.

The metabolism of 4-oxalocrotonate was observed spectrophotometrically by following a decrease in absorbance at $292 \mathrm{~nm}$ and an increase in absorbance at $235-240 \mathrm{~nm}$. This is consistent with previous reports of a tautomerization between the enol and keto forms of this compound (Sala-Trepat \& Evans, 1971a). The reaction occurs spontaneously, with a rate of decrease in absorbance at $292 \mathrm{~nm}$ of 3.3 units $\min ^{-1}\left(55^{\circ} \mathrm{C}, \mathrm{pH} \mathrm{7.0}\right)$. The cell-free extract of phenol-grown cells increased this rate of tautomerization by 400 units (mg protein) ${ }^{-1} \mathrm{~min}^{-1}$ (Table 2). The keto form of $O C$ was further degraded by cell-free extracts. This reaction was stimulated 11 -fold by $1 \mathrm{mM}-\mathrm{Mg}^{2+}$ and completely inhibited by $5 \mathrm{mM}$-EDTA. A transient product of the reaction was identified as 2-oxopent-4-enoate by HPLC analysis.

Authentic 2-oxopent-4-enoate yielded 4-hydroxy-2-oxovalerate in the presence of cell-free extracts from phenol-grown cells. The appearance of this product was again transient. The reaction was stimulated 36-fold by $1 \mathrm{mM} \mathrm{Mg}^{2+}$ and $\mathrm{Mn}^{2+}$ (Table 3). The metabolism of $4-$ hydroxy-2-oxovalerate proceeded by an aldolase reaction, preliminary experiments indicating that pyruvate and acetaldehyde were the reaction products. Triplicate incubations of phosphate buffer solutions $(1 \mathrm{ml})$ containing cell-free extract protein $(0.5 \mathrm{mg})$ and 4-hydroxy-2-oxovalerate $(0.5 \mu \mathrm{mol})$ were incubated at $55^{\circ} \mathrm{C}$ for $30 \mathrm{~min}$. The incubations were done in sealed microfuge tubes to prevent the escape of acetaldehyde (boiling point $21^{\circ} \mathrm{C}$ ). The solutions were then reassayed for 4-hydroxy-2-oxovalerate, pyruvate and acetaldehyde. On average, $78 \mathrm{nmol} \mathrm{4-}$ hydroxy-2-oxovalerate were degraded and $38 \mathrm{nmol}$ pyruvate and $22 \mathrm{nmol}$ acetaldehyde were produced. In further experiments, the maximum amount of synthetic 4-hydroxy-2-oxovalerate metabolized was $40 \%$.

The enzymes involved in the degradation of HMS to pyruvate and acetaldehyde were assayed in cell-free extracts prepared from glucose- and phenol-grown cells (Table 1-3). All of the 


\section{Table 1. Rates of disappearance of ring fission products}

Rates are expressed as nmol (mg protein)-1 $\mathrm{min}^{-1}$. All extracts were treated with 0.056 units NADase for $30 \mathrm{~min}$ at $37^{\circ} \mathrm{C}$. NAD was added to a final concentration of $1 \mathrm{mM}$. When NADP was added to the NADase-treated phenol-grown cell-free extracts, to a final concentration of $1 \mathrm{mM}$, the rate of HMS disappearance increased to $11.4 \mathrm{nmol}$ (mg protein) ${ }^{-1} \mathrm{~min}^{-1}$. ND, Not determined.

Ring fission product

2-Hydroxymuconic semialdehyde

2-Hydroxy-6-oxohepta-2,4-dienoate

2-Hydroxy-5-methylmuconic semialdehyde
Phenol-grown cells

\begin{tabular}{|c|c|c|c|}
\hline \multicolumn{2}{|c|}{ Without NAD } & \multicolumn{2}{|c|}{ With NAD } \\
\hline Rate & $\%$ & Rate & $\%$ \\
\hline 3.34 & 5 & 67.6 & 100 \\
\hline 4.04 & 6 & $4 \cdot 3$ & 6 \\
\hline 1.02 & 2 & 57.7 & 85 \\
\hline
\end{tabular}

Glucose-grown cells

\begin{tabular}{|c|c|c|c|}
\hline \multicolumn{2}{|c|}{ Without NAD } & \multicolumn{2}{|c|}{ With NAD } \\
\hline Rate & $\%$ & Rate & $\%$ \\
\hline $2 \cdot 1$ & 3 & $2 \cdot 1$ & 3 \\
\hline ND & - & ND & - \\
\hline ND & - & ND & - \\
\hline
\end{tabular}

Table 2. Activities of 4-oxalocrotonate-metabolizing enzymes

Tautomerase rates are expressed in absorbance units (mg protein)-1 $\mathrm{min}^{-1}$ and decarboxylase rates as nmol (mg protein) ${ }^{-1} \mathrm{~min}^{-1}$. Spontaneous disappearance of 4-oxalocrotonate was not observed in the absence of cell-free extracts. EDTA was added to a final concentration of $5 \mathrm{mM}$, and $\mathrm{MgSO}_{4}, 1 \mathrm{mM}$. ND, Not determined.

\begin{tabular}{|c|c|c|c|c|c|}
\hline \multirow[b]{3}{*}{ Enzyme } & \multirow[b]{3}{*}{ Addition } & \multicolumn{4}{|c|}{ Cells grown on: } \\
\hline & & \multicolumn{2}{|c|}{ Phenol } & \multicolumn{2}{|c|}{ Glucose } \\
\hline & & Rate & $\%$ & Rate & $\%$ \\
\hline $\begin{array}{l}\text { 4-Oxalocrotonate } \\
\text { tautomerase }\end{array}$ & $\begin{array}{l}\text { None } \\
\text { EDTA }\end{array}$ & $\begin{array}{l}400 \\
400\end{array}$ & $\begin{array}{l}100 \\
100\end{array}$ & $\begin{array}{c}0 \\
\text { ND }\end{array}$ & 0 \\
\hline $\begin{array}{l}\text { 4-Oxalocrotonate } \\
\text { decarboxylase }\end{array}$ & $\begin{array}{c}\text { None } \\
\text { EDTA } \\
\mathrm{MgSO}_{4}\end{array}$ & $\begin{array}{c}88 \cdot 5 \\
0 \\
963\end{array}$ & $\begin{array}{r}100 \\
0 \\
1090\end{array}$ & $\begin{array}{l}2.8 \\
\text { ND } \\
\text { ND }\end{array}$ & $\begin{array}{l}3 \\
- \\
-\end{array}$ \\
\hline
\end{tabular}

Table 3. Activities of 2-oxopent-4-enoate hydratase and 4-hydroxy-2-oxovalerate aldolase

All additions were added to final concentrations of $1 \mathrm{mM}$. Controls without cell-free extracts showed no significant rate of degradation above the background levels. ND, Not determined.

\begin{tabular}{|c|c|c|c|c|c|}
\hline \multirow[b]{3}{*}{ Enzyme } & \multirow[b]{3}{*}{ Addition } & \multicolumn{4}{|c|}{ Cells grown on: } \\
\hline & & \multicolumn{2}{|c|}{ Phenol } & \multicolumn{2}{|c|}{ Glucose } \\
\hline & & Rate & $\%$ & Rate & $\%$ \\
\hline $\begin{array}{l}\text { 2-Oxopent-4 } \\
\text { enoate hydratase }\end{array}$ & $\begin{array}{c}\text { None } \\
\mathrm{MgSO}_{4} \\
\mathrm{MnSO}_{4}\end{array}$ & $\begin{array}{l}0 \cdot 17 \\
6 \cdot 15 \\
6 \cdot 19\end{array}$ & $\begin{array}{r}100 \\
3600 \\
3600\end{array}$ & $\begin{array}{l}0 \\
\text { ND } \\
\text { ND }\end{array}$ & $\begin{array}{l}0 \\
- \\
-\end{array}$ \\
\hline $\begin{array}{l}\text { 4-Hydroxy-2-oxo- } \\
\text { valerate aldolase }\end{array}$ & $\begin{array}{l}\text { None } \\
\text { NAD }\end{array}$ & $\begin{array}{l}3 \cdot 83 \\
3 \cdot 58\end{array}$ & $\begin{array}{r}100 \\
93\end{array}$ & $\begin{array}{l}3.39 \\
\text { ND }\end{array}$ & $\begin{array}{c}89 \\
-\end{array}$ \\
\hline
\end{tabular}

enzymes, with the exception of HODH and 4-hydroxy-2-oxovalerate aldolase, were induced by growth on phenol.

\section{DISCUSSION}

The degradation of meta ring fission products by $B$. stearothermophilus IC3 is consistent with the pathway shown in Fig. 1. Similar pathways have been delineated in pseudomonads (Murray et al., 1972; Hopper \& Taylor, 1975), Alcaligenes eutrophus (Bayly et al., 1978) and Azotobacter species (Sala-Trepat \& Evans, 1971 a). 


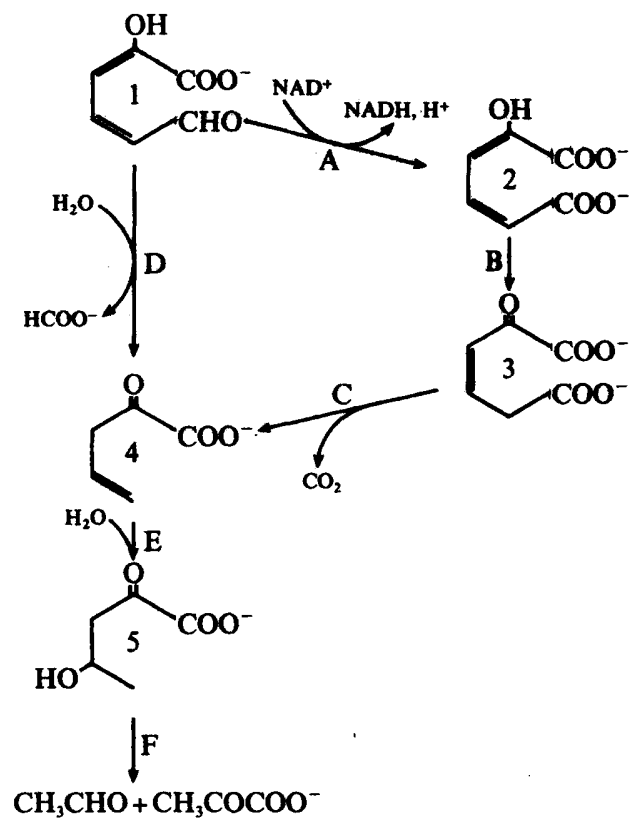

Fig. 1. Degradation of ring fission products. Numerals represent chemicals as follows: 1, 2hydroxymuconic semialdehyde; 2, 4-oxalocrotonate (enol form); 3, 4-oxalocrotonate (keto form); 4, 2oxopent-4-enoate; 5, 4-hydroxy-2-oxovalerate. Letters represent enzymes as follows: A, 2-hydroxymuconic semialdehyde dehydrogenase; B, 4-oxalocrotonate tautomerase; C, 4-oxalocrotonate decarboxylase; D, 2-hydroxy-6-oxohepta-2,4-dienoate hydrolase; E, 2-oxopent-4-enoate hydratase; F, 4-hydroxy-2-oxovalerate aldolase.

In strain IC3, two different enzymes appear to be responsible for the degradation of 2hydroxymuconic semialdehyde and its 5-methylated derivative. One of these enzymes, which is not NAD dependent, gives formate as a reaction product. The results indicate that the reaction may be catalysed by an HODH. The other product of the reaction of HODH upon HMS has previously been shown to be 2-oxopent-4-enoate (Dagley \& Gibson 1965). This is assumed to be the other product in hydrolytic HMS metabolism by strain IC3, but it has not been directly demonstrated as such.

As observed in previous reports, the hydrolase enzyme has a greater activity towards HOD than HMS or HMMS. However, the relative activities of the enzyme from strain IC3 towards HMS and HMMS were much greater than those observed in B. stearothermophilus PH24 (Buswell, 1974), Pseudomonas putida strains NCIB 10015, NCIB 9865 (Bayly \& Di Berardino, 1978) and mt-2 (Duggleby \& Williams, 1986), and Alcaligenes eutrophus 345 (Bayly et al., 1987).

The alternative route for the metabolism of ring fission products in the thermophile is an NAD-mediated dehydrogenation. The enzyme, HMSD, quantitatively converts HMS into 4oxalocrotonate. The enzyme also attacks HMMS, but the product was not determined. The ketone product of 3-methylcatechol ring cleavage, HOD, was not a substrate for the dehydrogenase. These results are similar to those observed with the dehydrogenase from several Azotobacter species (Sala-Trepat \& Evans, $1971 a, b$ ) and $P$. putida mt-2 (Murray et al., 1972).

Previous workers have suggested that the hydrolytic route, where the oxidative route is present, is utilized in the metabolism of compounds which yield HOD and analogous ketones, while the oxidative route is used for the metabolism of compounds which give aldehyde intermediates. When HMSD activity is absent, HMS and its methyl substituted analogues can be metabolized hydrolytically (Bayly \& Dagley, 1969). In contrast, HMSD will only metabolize HMS and HMMS. Consequently, organisms such as Azotobacter vinelandii that only display low, non-inducible levels of the hydrolase, possibly of an unrelated pathway, cannot grow on compounds such as o-cresol that yield HOD (Sala-Trepat \& Evans, 1971 a). 
4-Oxalocrotonate was identified as an intermediate in the degradation of catechol by Nishizuka et al. (1962). Subsequently, it was shown to be degraded by a tautomerization from the enol to the keto form, followed by a decarboxylation, yielding 2-oxopent-4-enoate (SalaTrepat \& Evans, 1971 a). The results in Table 2 show that strain IC 3 also possesses an inducible 4-oxalocrotonate tautomerase activity. The fact that this enzyme is necessary for growth, despite the rapid spontaneous rate of tautomerization, has been verified by a number of workers (Wigmore et al., 1974; Barbour \& Bayly, 1980; Harayama et al., 1987). The activity of the decarboxylase enzyme, like those reported previously, was stimulated by $\mathbf{M g}^{2+}$ ions and inhibited by EDTA.

Strain IC3 also possesses a 2-oxopent-4-enoate hydratase activity. This activity is stimulated 36-fold by both $\mathrm{Mg}^{2+}$ and $\mathrm{Mn}^{2+}$ ions. Collinsworth et al. (1973) found that a similar enzyme activity in $P$. putida was stimulated 5-fold by $\mathrm{Mn}^{2+}$, no stimulation being observed in the presence of $\mathrm{Mg}^{2+}$. Another $P$. putida 2-oxopent-4-enoate hydratase activity was stimulated 7and 2-fold by $\mathrm{Mn}^{2+}$ and $\mathrm{Mg}^{2+}$ ions respectively (Lampel, 1979).

The 2-oxopent-4-enoate hydratase and 4-hydroxy-2-oxovalerate aldolase were found to be stereospecific in other organisms. Collinsworth et al. (1973) concluded that L-(S)-4-hydroxy-2oxovalerate was the biologically active enantiomer in the degradation of aromatic compounds by $P$. putida NCIB 10015 . The fact that only $40 \%$ of the synthetic 4-hydroxy-2-oxovalerate was metabolized by the thermophilic extracts suggests that the hydratase and aldolase reactions are also stereospecific in B. stearothermophilus IC3, although the biologically active enantiomer was not determined.

The results demonstrate that 4-hydroxy-2-oxovalerate was degraded to pyruvate and acetaldehyde. This reaction indicates the presence of an aldolase enzyme similar to that described by Dagley \& Gibson (1965). The metabolism of 4-hydroxy-2-oxovalerate was not stimulated by the presence of NAD. This suggests that acetylpyruvate is not an intermediate, as reported for some pseudomonads (Nishizuka et al., 1962).

Most of the degradative enzymes were only present when strain IC3 was grown on phenol. However, the HODH and 4-hydroxy-2-oxovalerate aldolase were present in significant amounts in cell-free extracts prepared from glucose-grown cells. The constitutive but low production of HODH has been noted in Azotobacter species (Sala-Trepat \& Evans, 1971 b). These strains were unable to grow on compounds producing 2-hydroxy-6-oxohepta-2,4-dienoate. The Azotobacter strains also possessed a constitutive 4-hydroxy-2-oxovalerate aldolase. This reaction in both the mesophile and $B$. stearothermophilus may be catalysed by a non-specific enzyme which also has different functions within the bacterial cell.

The metabolism of ring fission products by $B$. stearothermophilus IC3 is similar to the metabolism of these compounds in mesophiles, all of the enzymes being functional at $55^{\circ} \mathrm{C}$. However, as no data are available on the heat optima or stability of the enzymes, this would be a useful objective for further studies.

We would like to thank the Science and Engineering Research Council for a studentship awarded to D. Adams. We would also like to thank Dr John Rossiter for synthesizing 4-oxalocrotonate and 4-methyl-2-oxobutyrolactone.

\section{REFERENCES}

ADAMs, D. \& RIBbons, D. W. (1988). The metabolism of aromatic compounds by thermophilic bacilli. Applied Biochemistry and Biotechnology 17, 231-244.

BARbour, M. G. \& BAYLY, R. C. (1980). Mutants defective in isomerase and decarboxylase activities of the 4-hydroxyphenylacetic acid meta cleavage pathway in Pseudomonas putida. Jounral of Bacteriology 142, 480-485.

BAYLY, R. C. \& DAgley, S. (1969). Oxoenoic acids as metabolites in the bacterial degradation of catechols. Biochemical Joumal 111, 303-307.

BAYLY, R. C. \& DI Berardino, D. (1978). Purification and properties of 2-hydroxy-6-oxo-2,4-heptadi- enoate hydrolase from two strains of Pseudomonas putida. Journal of Bacteriology 134, 30-37.

BAyLy, R. C., Di Berardino, D., Hughes, E. J. L. \& Sxurray, R. A. (1987). The purification and properties of two isofunctional 2-hydroxy-6-0xohepta-2,4-dienoate hydrolases from Alcaligenes eutrophus strain 345. Journal of General Microbiology 133, 815-822.

BrADFORD, M. M. (1976). A rapid and sensitive method for the quantitation of microgram quantities of protein utilizing the principle of protein-dye binding. Analytical Biochemistry 72, 248-254.

Brown, J. P. \& Perham, R. N. (1976). Selective 
inactivation of the transacylase components of the 2oxo acid dehydrogenase multienzyme complex of Escherichia coli. Biochemical Journal 155, 419-427.

Buswell, J. A. (1974). The meta cleavage of catechol by a thermophilic Bacillus species. Biochemical and Biophysical Research Communications 60, 934-941.

Buswell, J. A. (1975). Metabolism of phenols and cresols by Bacillus stearothermophilus. Journal of Bacteriology 124, 1077-1083.

Buswell, J. A. \& Clark, J. S. (1976). Oxidation of aromatic acids by a facultative thermophilic Bacillus sp. Journal of General Microbiology 96, 209-213.

Buswell, J. A. \& TwomeY, D. G. (1974). Aromatic acid oxidation by a thermophilic bacterium. Proceedings of the Society for General Microbiology 1, 48.

Buswell, J. A. \& TwomeY, D. G. (1975). Utilization of phenols and cresols by Bacillus stearothermophilus strain PH24. Journal of General Microbiology 87, 377-379.

Collnnsworth, W. L., Chapman, P. J. \& Dagley, S. (1973). Stereospecific enzymes in the degradation of aromatic compounds by Pseudomonas putida. Journal of Bacteriology 133, 922-931.

DAGLEY, S. \& Gibson, D. T. (1965). The bacterial degradation of catechol. Biochemical Journal 95, 466474.

Degryse, E., Glansdorf, N. \& Pifrard, A. (1978). A comparative analysis of extreme thermophilic bacteria belonging to the genus Thermus. Archives of Microbiology 117, 189-196.

DugGleby, C. J. \& Williams, P. A. (1986). Purification and some properties of the 2-hydroxy-6oxohepta-2,4-dienoate hydrolase (2-hydroxymuconic semialdehyde hydrolase) encoded by the TOL plasmid pWWO from Pseudomonas putida mt-2. Journal of General Microbiology 132, 717-726.

Egorova, A. A. (1942). Okislenie fieslov termofilnymi organizmami. Mikrobiologiya 11, 131-133.

Egorovi, A. A. (1946). Nekotrye dannye o fiziologii bakteriy okislyayuschikh fenol pri vysokikh temperaturakh. Microbiologiya 15, 467-477.

Golovacheva, R. S. \& OREshixin, A. E. (1975). Oxidation of phenol by certain strains of Bacillus stearothermophilus. Microbiology (USSR) 44, 470475. (English translation. New York: Plenum Press.)

GraNT, W. M. (1948). Colorimetric microdetermina- tion of formic acid based on reduction to formaldehyde. Analytical Chemistry 20, 267-269.

Harayama, S., Mermod, N., Rekik, M., Lehrbach, P. R. \& Timmis, K. N. (1987). Roles of the divergent branches of the meta-cleavage pathways in the degradation of benzoate and substituted benzoates. Journal of Bacteriology 169, 558-564.

HOPPER, D. J. \& TAYLOR, D. G. (1975). Pathways for the degradation of $m$-cresol and p-cresol by Pseudomonas putida. Journal of Bacteriology 122, 1-6.

LAMPEL, K. A. (1979). The p-cymene pathway in Pseudomonas putida: a comparative study of the three enzymes catalysing sequential reactions subsequent to ring cleavage. $\mathrm{PhD}$ dissertation, University of Miami, USA

LAPWORTH, A. (1901). Form of change in organic compounds and the function of the $\alpha$-meta orientating groups. Journal of the Chemical Society 79, 12651284.

LUNDQUIST, F. (1958). Enzymic determination of acetaldehyde in blood. Biochemical Journal 68, 172177.

MurRay, K., Duggleby, C. J., SAla-Trepat, J. M. \& Williams, P. A. (1972). The metabolism of benzoate and methylbenzoates via the meta cleavage pathway by Pseudomonas arvilla mt-2. European Journal of Biochemistry 28, 301-310.

NishizuKa, Y., IchiYama, A., Nakamura, S. \& HAYAISH, O. (1962). A new metabolic pathway of catechol. Journal of Biological Chemistry 237, PC268270.

Rossi, A. \& Schinz, H. (1948). Alcuni $\alpha$-cheto-gamma lattoni con sostituenti alchilici in posizione gamma. Helvetica chimica acta 31, 473-492.

Sala-Trepat, J. M. \& Evans, W. C. (1971 a). The meta cleavage of catechol by Azotobacter species. European Journal of Biochemistry 20, 400-413.

Sala-Trepat, J. M. \& Evans, W. C. (1971b). The metabolism of 2-hydroxymuconic semialdehyde by Azotobacter species. Biochemical and Biophysical Research Communications 43, 456-462.

Wigmore, G. J., BAYLY, R. C. \& Di Berardino, D. (1974). Pseudomonas putida mutants defective in the metabolism of the products of meta fission of catechol and its methyl analogues. Journal of Bacteriology 120, 31-37. 